\title{
Distribution and Flora of Seaweed Beds in the Coastal Waters of China
}

\author{
Xunmeng $\mathrm{Li}^{\dagger}{ }^{\dagger}$, Kai Wang ${ }^{*}+$, Shouyu Zhang * and Meiping Feng \\ College of Marine Ecology and Environment, Shanghai Ocean University, Shanghai 201306, China; \\ d180400069@st.shou.edu.cn (X.L.); mpfeng@shou.edu.cn (M.F.) \\ * Correspondence: kwang@shou.edu.cn (K.W.); syzhang@shou.edu.cn (S.Z.) \\ + These authors contributed to the work equally and should be regarded as co-first authors.
}

Citation: Li, X.; Wang, K.; Zhang, S.; Feng, M. Distribution and Flora of Seaweed Beds in the Coastal Waters of China. Sustainability 2021, 13, 3009. https://doi.org/10.3390/su13063009

Academic Editor: Konstantinos Ar. Kormas

Received: 21 January 2021

Accepted: 8 March 2021

Published: 10 March 2021

Publisher's Note: MDPI stays neutral with regard to jurisdictional claims in published maps and institutional affiliations.

Copyright: (c) 2021 by the authors. Licensee MDPI, Basel, Switzerland. This article is an open access article distributed under the terms and conditions of the Creative Commons Attribution (CC BY) license (https:// creativecommons.org/licenses/by/ $4.0 /)$.

\begin{abstract}
Seaweed plays an important role in energy production in marine, coastal, and island ecosystems. The protection of seaweed beds is a key point for coastal ecosystem health, but the community characteristics, dominant species, and distribution of seaweed beds in the coastal waters of China are still unknown. Dividing seaweed beds based on their ecological function is also required for coastal ecosystem conservation, marine development, and utilization. We conducted ecological surveys on various types of ecosystems at approximately 50 sites dedicated to the conservation of seaweed bed biodiversity in China from 2018 to 2019. These seaweed beds were classified into different flora by water temperature and the attributes of the dominant species. The study showed that Sargassum dominated the coast of China. The coverage of the genus Undaria and the genus Laminaria in the coastal waters of Liaoning and Shandong was high and gradually decreased from Zhejiang to the south. The mean biomass of the seaweed beds along the coast of China was $7.29 \mathrm{~kg} / \mathrm{m}^{2}$, and the mean coverage was $41.25 \%$. The height and fresh weight of the dominant species gradually decreased with the decreasing latitude. The seaweed beds were distributed from the shallow water zone to the profundal zone along the coast from north to south, and the bathymetry of seaweed beds in Hainan was below $6 \mathrm{~m}$. Based on the water temperature, the attributes of the seaweed beds, the temperature attributes of the dominant species, and the seaweed's distribution, the seaweed beds in China can be specifically divided into temperate warm water types, subtropical warm water types, and tropical warm water types. This study is relevant to the development of regulations and directives to ensure biodiversity conservation and environmental sustainability.
\end{abstract}

Keywords: seaweed beds; ecosystem; distribution characteristics; flora division; dominant species

\section{Introduction}

Seaweed beds are areas where large amounts of benthic seaweed thrive in the several tens of meters of the intertidal and subtidal zones. They are widely distributed along the continental coasts of the cold temperate zone and some of the tropical and subtropical coasts [1,2]. Most dominant species belong to the Ochrophyta, Rhodophyta, and Chlorophyta phyla. Among them, Ochrophyta has the most extensive distribution in seaweed beds, including Macrocystis, Sargassum, and Laminaria [3].

Seaweed beds are of great ecological importance within the coastal ecosystem, serving as food, habitats, and nurseries for many associated biological organisms [4-8]; and as one of the typical sub-ecosystems in coastal waters, seaweed beds, together with coral reefs, mangrove forests, and seagrass meadows, constitute a coastal offshore ecosystem with complex structures and species diversity [9-11].

In recent years, following the aggravation of the pollution of aquaculture in coastal environments, the expansion of ocean engineering, gradual ocean warming, and the disorderly harvesting of seaweeds, there has been a rapid depletion of resources in coastal seaweed beds, and the resource situation of existing coastal seaweed beds has gradually become the central focus of many researchers [12-16]. Prior to this study, systematic on-site 
sampling and surveys of seaweed beds in the subtidal zone with high productivity and outstanding ecological functions had not been performed.

In addition, due to the low transparency of coastal waters in China and the canopy of large seaweeds rarely surfacing, it is difficult even in the present to use modern satellite remote sensing methods to assess the species distribution and biomass [17,18]. In addition, the latest distribution map of global seaweed beds drawn by European and American researchers does not show the distribution of seaweed near the coast of China [19]. Therefore, little is known regarding the geographic distribution, bathymetry range, sediment types, dominant species, abundance, scale, seasonal changes, and community ecology of the coastal seaweed beds of China.

Seaweed beds are some of the most informative long-term markers of any coastal marine environment; the distribution of seaweeds and the biodiversity of the different beds also significantly differ due to the different geographical regions in which they grow, and thus they often have particular ecological and geographical traits [20]. The flora of seaweed beds has important ecological scientific value, which can promote the cognition, protection, and rational development of seaweed resources.

Until now, the division of seaweed flora has been carried out through generalization [21]. Tseng and Chang (1959) successively put forward a series of preliminary suggestions regarding the division of seaweed flora on the coast of China and the west coast of the North Pacific [22]. However, the basis for the division of seaweed flora in their study depended only on the temperature attributes of singular seaweed and thus did not consider the community characteristics and macro-scale of the seaweed beds as a whole [23]. Regarding the compositions of seaweed beds, different species have different ecological functions, and the biomasses and ecological functions of certain dwarf seaweeds are far less substantial than those of the dominant seaweed [24].

In this paper, we summarize the results for every seaweed bed, including the characteristic distribution, composition of seaweed species, and flora characteristics, of the coastal seaweed beds in China. Based on the national survey data of coastal seaweed beds conducted from 2018 to 2019, we analyzed the distribution of seaweed beds and supplemented the databank with the distribution of seaweed beds in the subtidal zone of China. Utilizing previous research, some comparative analyses were completed based on the structural characteristics, temperature attributes, geographic distribution, and the differences between adjacent regions. We provide a suggestion for the division of coastal seaweed beds in China; we expect that the information and insights provided by this study will be able to assist the government in designing policies related to the conservation of seaweed beds.

\section{Methods}

\subsection{Monitoring Sites}

We conducted a survey of seaweed beds from Dong Gang Shi (DGS), Liaoning, in the north of China ( $\left.39^{\circ} 50^{\prime} 20.02^{\prime \prime} \mathrm{N}, 124^{\circ} 10^{\prime} 18.58^{\prime \prime} \mathrm{E}\right)$, to Da Dong Hai (DDH), Hainan, in the south $\left(18^{\circ} 12^{\prime} 47.56^{\prime \prime} \mathrm{N}, 109^{\circ} 30^{\prime} 36.56^{\prime \prime} \mathrm{E}\right)$, between 2018 and 2019 (Figure 1).

These surveys pertained to the distribution characteristics of the dominant species, sediment types, height, coverage, bathymetry, water temperature, salinity, and biomass of the coastal seaweed beds (Table 1). Comprehensive analysis of the historical documents, the natural distribution characteristics, and the environmental features of different places was performed, and then the key coastal seaweed beds that were less affected by humans were selected for investigation (regional representatives). In the course of the investigation, some supplemental information was obtained based on the visits of local fishery management and fishermen, and important seaweed bed investigations were added. 


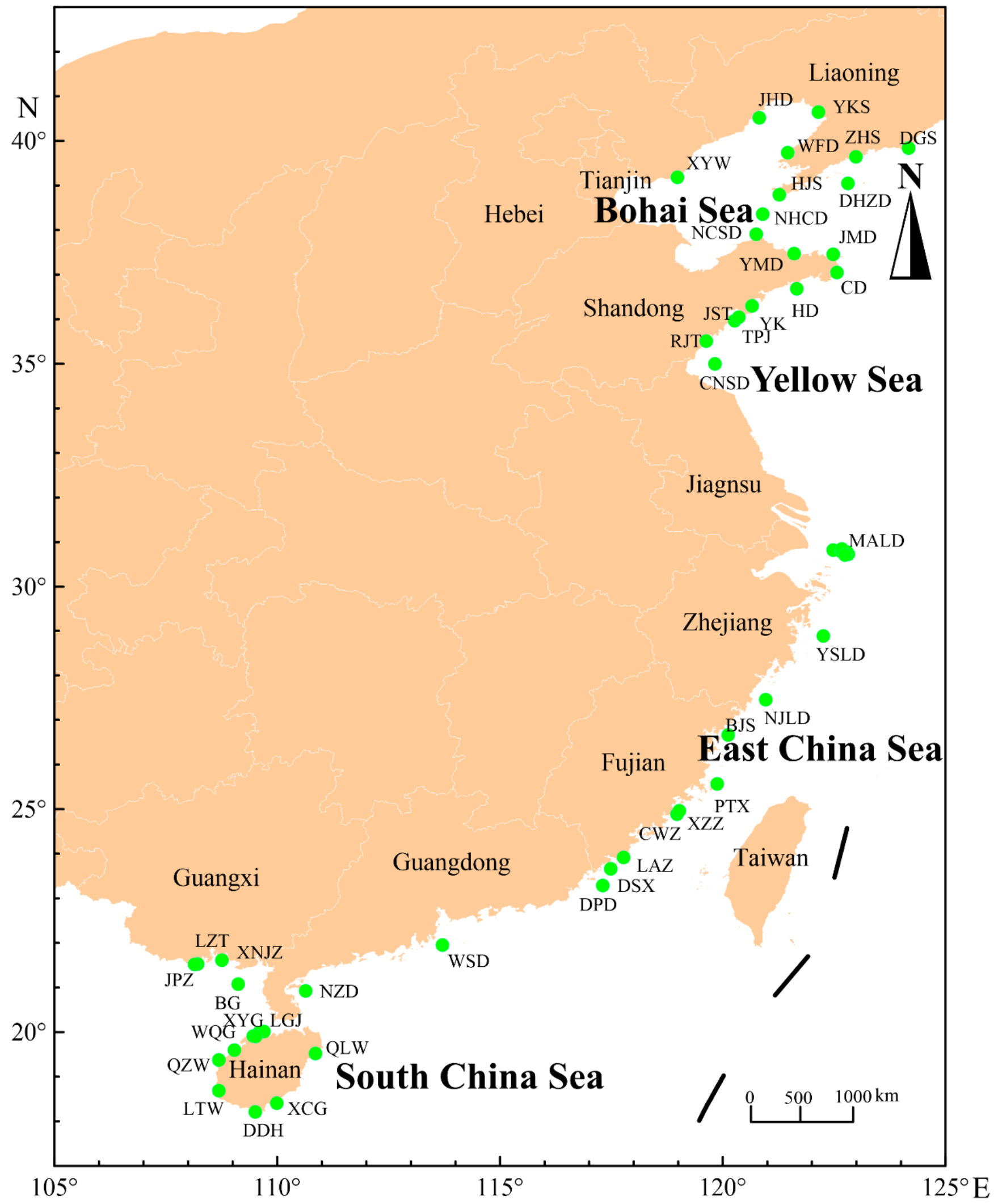

Figure 1. Survey sites of seaweed beds in the coastal subtidal zone. 
Table 1. Sites of seaweed beds and their water quality.

\begin{tabular}{|c|c|c|c|c|}
\hline Site & Latitude & Longitude & $\begin{array}{c}\text { Water Temperature } \\
\left({ }^{\circ} \mathrm{C}\right)\end{array}$ & Salinity (\%o) \\
\hline HJS (Huang Jin Shan) & $38^{\circ} 47^{\prime} 30.29^{\prime \prime}$ & $121^{\circ} 16^{\prime} 10.55^{\prime \prime}$ & $19.18-24.28$ & $29.8-31.8$ \\
\hline $\begin{array}{c}\text { DHZD (Da Hao } \\
\text { Zi Dao) }\end{array}$ & $39^{\circ} 02^{\prime} 58.25^{\prime \prime}$ & $122^{\circ} 48^{\prime} 49.28^{\prime \prime}$ & $17.11-21.04$ & $30.7-31.7$ \\
\hline JHD (Jue Hua Dao) & $40^{\circ} 30^{\prime} 49.77^{\prime \prime}$ & $120^{\circ} 49^{\prime} 16.37^{\prime \prime}$ & $26.20-26.27$ & $34.14-34.66$ \\
\hline WFD (Wa Fang Dian) & $39^{\circ} 44^{\prime} 13.09^{\prime \prime}$ & $121^{\circ} 27^{\prime} 26.11^{\prime \prime}$ & $26.48-26.83$ & $33.99-34.03$ \\
\hline XYW (Xiang Yun Wan) & $39^{\circ} 10^{\prime} 42.04^{\prime \prime}$ & $118^{\circ} 58^{\prime} 50.39^{\prime \prime}$ & $24.93-26.64$ & 31.4-32.2 \\
\hline YKS (Ying Kou Shi) & $40^{\circ} 38^{\prime} 37.95^{\prime \prime}$ & $122^{\circ} 08^{\prime} 55.58^{\prime \prime}$ & - & - \\
\hline DGS (Dong Gang Shi) & $39^{\circ} 50^{\prime} 20.02^{\prime \prime}$ & $124^{\circ} 10^{\prime} 18.58^{\prime \prime}$ & - & - \\
\hline ZHS (Zhuang He Shi) & $39^{\circ} 38^{\prime} 27.64^{\prime \prime}$ & $122^{\circ} 59^{\prime} 11.26^{\prime \prime}$ & - & - \\
\hline JST (Jin Sha Tan) & $35^{\circ} 58^{\prime} 02.58^{\prime \prime}$ & $120^{\circ} 16^{\prime} 11.13^{\prime \prime}$ & $22.56-23.33$ & $31.7-32.0$ \\
\hline YMD (Yang Ma Dao) & $37^{\circ} 28^{\prime} 08.14^{\prime \prime}$ & $121^{\circ} 36^{\prime} 20.50^{\prime \prime}$ & $20.33-22.95$ & $31-32.1$ \\
\hline $\begin{array}{l}\text { NHCD (Nan Huang } \\
\text { Cheng Dao) }\end{array}$ & $38^{\circ} 21^{\prime} 25.33^{\prime \prime}$ & $120^{\circ} 53^{\prime} 49.35^{\prime \prime}$ & $17.37-20.65$ & $30.8-32.2$ \\
\hline $\begin{array}{l}\text { NCSD (Nan Chang } \\
\text { Shan Dao) }\end{array}$ & $37^{\circ} 54^{\prime} 29.76^{\prime \prime}$ & $120^{\circ} 45^{\prime} 18.53^{\prime \prime}$ & $20.44-21.76$ & $32.1-32.9$ \\
\hline HD (Hui Dao) & $36^{\circ} 41^{\prime} 02.22^{\prime \prime}$ & $121^{\circ} 39^{\prime} 36.79^{\prime \prime}$ & $26.64-30.43$ & $31.3-32.5$ \\
\hline CD (Chu Dao) & $37^{\circ} 02^{\prime} 37.73^{\prime \prime}$ & $122^{\circ} 33^{\prime} 42.23^{\prime \prime}$ & $23.02-25.59$ & $31.9-32.2$ \\
\hline JMD (Ji Ming Dao) & $37^{\circ} 27^{\prime} 08.73^{\prime \prime}$ & $122^{\circ} 28^{\prime} 51.65^{\prime \prime}$ & $24.61-26.20$ & 31.0-31.9 \\
\hline RJT (Ren Jia Tai) & $35^{\circ} 30^{\prime} 29.45^{\prime \prime}$ & $119^{\circ} 37^{\prime} 32.59^{\prime \prime}$ & $22.70-22.85$ & $32.57-33.58$ \\
\hline TPJ (Tai Ping Jiao) & $36^{\circ} 02^{\prime} 30.97^{\prime \prime}$ & $120^{\circ} 21^{\prime} 30.37^{\prime \prime}$ & $24.57-25.80$ & $32.96-33.03$ \\
\hline YK (Yang Kou) & $36^{\circ} 18^{\prime} 10.25^{\prime \prime}$ & $120^{\circ} 39^{\prime} 40.04^{\prime \prime}$ & $20.89-21.12$ & $32.47-32.51$ \\
\hline $\begin{array}{l}\text { CNSD (Che Niu } \\
\text { Shan Dao) }\end{array}$ & $34^{\circ} 59^{\prime} 38.85^{\prime \prime}$ & $119^{\circ} 49^{\prime} 21.67^{\prime \prime}$ & $25.62-26.39$ & $31.07-31.21$ \\
\hline NJD (Nan Ji Dao) & $27^{\circ} 27^{\prime} 30.76^{\prime \prime}$ & $120^{\circ} 57^{\prime} 57.00^{\prime \prime}$ & $21.71-22.76$ & $30.0-31.4$ \\
\hline YSD (Yu Shan Dao) & $28^{\circ} 53^{\prime} 10.29^{\prime \prime}$ & $122^{\circ} 15^{\prime} 17.71^{\prime \prime}$ & - & - \\
\hline SSD (Sheng Shan Dao) & $30^{\circ} 43^{\prime} 42.93^{\prime \prime}$ & $122^{\circ} 49^{\prime} 14.76^{\prime \prime}$ & $20.30-23.06$ & $8.06-8.16$ \\
\hline BXD (Bi Xia Dao) & $30^{\circ} 46^{\prime} 44.18^{\prime \prime}$ & $122^{\circ} 47^{\prime} 05.48^{\prime \prime}$ & - & - \\
\hline LHD (Lv Hua Dao) & $30^{\circ} 49^{\prime} 20.88^{\prime \prime}$ & $122^{\circ} 28^{\prime} 28.35^{\prime \prime}$ & $22.34-22.45$ & $23.2-23.6$ \\
\hline SHS (San Heng Shan) & $30^{\circ} 47^{\prime} 21.23^{\prime \prime}$ & $122^{\circ} 39^{\prime} 50.96^{\prime \prime}$ & $22.22-22.61$ & $24.5-24.9$ \\
\hline HND (Hua Niao Dao) & $30^{\circ} 50^{\prime} 47.64^{\prime \prime}$ & $122^{\circ} 40^{\prime} 12.39^{\prime \prime}$ & $21.19-22.81$ & $25.7-39.0$ \\
\hline GQD (Gou Qi Dao) & $30^{\circ} 42^{\prime} 52.61^{\prime \prime}$ & $122^{\circ} 44^{\prime} 14.28^{\prime \prime}$ & $24.10-25.59$ & $29.7-30.7$ \\
\hline LAZ (Liu Ao Zhen) & $23^{\circ} 54^{\prime} 52.81^{\prime \prime}$ & $117^{\circ} 46^{\prime} 23.20^{\prime \prime}$ & $24.84-25.00$ & $34.12-34.22$ \\
\hline DSX (Dong Shan Xian) & $23^{\circ} 39^{\prime} 51.25^{\prime \prime}$ & $117^{\circ} 29^{\prime} 08.82^{\prime \prime}$ & $24.31-24.59$ & $34.83-34.87$ \\
\hline BJS (Bi Jia Shan) & $26^{\circ} 39^{\prime} 35.58^{\prime \prime}$ & $120^{\circ} 07^{\prime} 24.84^{\prime \prime}$ & $23.48-24.40$ & $31.50-31.59$ \\
\hline $\begin{array}{c}\text { CWZ (Chong } \\
\text { Wu Zhen) }\end{array}$ & $24^{\circ} 53^{\prime} 24.15^{\prime \prime}$ & $118^{\circ} 58^{\prime} 29.84^{\prime \prime}$ & 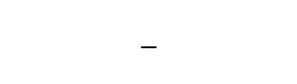 & 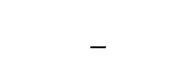 \\
\hline XZZ (Xiao Zuo Zhen) & $24^{\circ} 57^{\prime} 33.29^{\prime \prime}$ & $119^{\circ} 01^{\prime} 25.70^{\prime \prime}$ & - & - \\
\hline PTX (Ping Tan Xian) & $25^{\circ} 34^{\prime} 04.47^{\prime \prime}$ & $119^{\circ} 52^{\prime} 31.99^{\prime \prime}$ & $23.25-23.26$ & $28.70-28.71$ \\
\hline DPD (Ding Peng Dao) & $23^{\circ} 17^{\prime} 05.10^{\prime \prime}$ & $117^{\circ} 18^{\prime} 25.11^{\prime \prime}$ & $24.59-24.68$ & $8.27-8.28$ \\
\hline NZD (Nao Zhou Dao) & $20^{\circ} 55^{\prime} 35.29^{\prime \prime}$ & $110^{\circ} 38^{\prime} 15.52^{\prime \prime}$ & $24.73-24.95$ & $29.77-29.79$ \\
\hline WSD (Wan Shan Dao) & $21^{\circ} 57^{\prime} 03.40^{\prime \prime}$ & $113^{\circ} 42^{\prime} 38.41^{\prime \prime}$ & - & - \\
\hline BG (Bei Gang) & $21^{\circ} 04^{\prime} 26.63^{\prime \prime}$ & $109^{\circ} 07^{\prime} 17.66^{\prime \prime}$ & - & - \\
\hline LZT (Long Zhen Tai) & $21^{\circ} 31^{\prime} 39.63^{\prime \prime}$ & $108^{\circ} 12^{\prime} 38.78^{\prime \prime}$ & $25.97-26.02$ & $32.16-32.18$ \\
\hline $\begin{array}{l}\text { XNJZ (Xi Niu } \\
\text { Jiao Zhen) }\end{array}$ & $21^{\circ} 36^{\prime} 56.55^{\prime \prime}$ & $108^{\circ} 45^{\prime} 26.73^{\prime \prime}$ & - & - \\
\hline JPZ (Jiang Ping Zhen) & $21^{\circ} 31^{\prime} 12.31^{\prime \prime}$ & $108^{\circ} 08^{\prime} 40.64^{\prime \prime}$ & - & - \\
\hline QLW (Qing Lan Wan) & $19^{\circ} 31^{\prime} 16.65^{\prime \prime}$ & $110^{\circ} 51^{\prime} 39.06^{\prime \prime}$ & $24.16-25.78$ & $34.01-34.35$ \\
\hline XCG (Xin Cun Gang) & $18^{\circ} 24^{\prime} 09.86^{\prime \prime}$ & $109^{\circ} 59^{\prime} 23.41^{\prime \prime}$ & - & - \\
\hline DDH (Da Dong Hai) & $18^{\circ} 12^{\prime} 47.56^{\prime \prime}$ & $109^{\circ} 30^{\prime} 36.56^{\prime \prime}$ & - & - \\
\hline LTW (Ling Tou Wan) & $18^{\circ} 41^{\prime} 10.85^{\prime \prime}$ & $108^{\circ} 41^{\prime} 36.55^{\prime \prime}$ & - & - \\
\hline QZW (Qi Zi Wan) & $19^{\circ} 22^{\prime} 30.76^{\prime \prime}$ & $108^{\circ} 41^{\prime} 11.57^{\prime \prime}$ & - & - \\
\hline WQG (Wen Qing Gou) & $19^{\circ} 35^{\prime} 53.13^{\prime \prime}$ & $109^{\circ} 02^{\prime} 35.25^{\prime \prime}$ & $29.57-29.63$ & $34.99-35.01$ \\
\hline BZC (Bo Zong Cun) & $19^{\circ} 59^{\prime} 11.92^{\prime \prime}$ & $109^{\circ} 35^{\prime} 26.45^{\prime \prime}$ & $24.16-25.78$ & $34.01-34.35$ \\
\hline LCJ (Lin Chang Jiao) & $19^{\circ} 54^{\prime} 42.82^{\prime \prime}$ & $109^{\circ} 27^{\prime} 41.29^{\prime \prime}$ & - & - \\
\hline LGJ (Lin Gao Jiao) & $20^{\circ} 01^{\prime} 03.50^{\prime \prime}$ & $109^{\circ} 42^{\prime} 15.86^{\prime \prime}$ & $24.68-24.97$ & $34.0-34.1$ \\
\hline XYG (Xin Ying Gang) & $19^{\circ} 54^{\prime} 26.67^{\prime \prime}$ & $109^{\circ} 31^{\prime} 04.26^{\prime \prime}$ & - & - \\
\hline
\end{tabular}




\subsection{Collection of Samples}

Surveys were carried out during the season when the dominant species of seaweeds were the most abundant. A nondestructive quadrat sampling method, with quadrats placed along transects perpendicular to the shoreline, was used to determine the species composition, biomass, coverage, and density at these sites. The BioSonics MX digital echo sounder was used to investigate the height and coverage of the seaweed. The frequency was $204.8 \mathrm{kHz}$ and the pulse duration was $0.4 \mathrm{~ms}$. The pulse repetition rate was $5 \mathrm{ping} / \mathrm{s}$ and the single beamwidth was $8.3^{\circ}$.

The sonar transducer was placed vertically into seawater to generate accurate measurements of the seaweed canopy height and percentage cover and bathymetry. A Cast Away-CTD (conductivity, temperature, and depth) multiparameter water quality monitoring instrument was used to monitor the water's parameters, such as the water temperature, salinity, and bathymetry, at each site. The sonar survey included three routes-the inner route, the outer route, and the "S" shape between them. The transects were set according to the seaweed distribution. Three transect lines were positioned perpendicular to the shoreline at each site. Combined with the slope of the underwater terrain, the surveyed region was divided into three depth areas: I, II, and III.

Cross-section sampling was conducted through SCUBA diving. The percentage cover of seaweed was estimated, and $30 \times 30 \mathrm{~cm}^{2}$ quadrats were placed along the transect from the shallow water zone to the profundal zone every meter. Three to five parallel samples were collected at the same bathymetry, and the time and bathymetry of each sample position were recorded [25]. While the quantitative samples were collected, the nearby qualitative samples were collected in situ as supplementary data.

After the seaweed samples were collected, cleaned with seawater, and brought back to the laboratory, we measured the biological characteristics of their height and fresh weight. After that, we soaked them in 5\% formalin solutions, listed and numbered them according to the classification system, and stored the qualitative and quantitative samples separately. This survey was performed at approximately 50 candidate sites throughout China. We took 9-10 samples at each sampling site, and 500 transects were performed, totaling 4500 samples. The sonar survey swept about $1100 \mathrm{~km}$ in total.

\subsection{Data Analysis}

The data collected from the echo sounder were analyzed by Visual Habitat software, and the bathymetry of each quadrat was standardized according to the local tidal variation.

The importance value (IV), which represents the dominance of seaweeds, can be calculated as:

$$
I V_{i}=\left(\frac{B_{i}}{B}\right) \times f_{i}
$$

where $I V_{i}$ is the importance value of $i$ species; $B_{i}$ is the biomass $(\mathrm{g})$ of $i$ species; $B$ is the total biomass ( $\mathrm{g}$ ) of seaweeds; and $f_{i}$ is the occurrence frequency of $i$ species. Based on the calculated importance value $\left(I V_{i}>0.02\right)$, we were able to determine whether a species was the local dominant species [26].

The data were analyzed using SPSS version 25 (SPSS Inc., Chicago, IL, USA). The data were expressed as mean \pm standard deviation (SD). For the mean height and weight, a comparison of different sites was performed with ANOVA. $p<0.05$ was considered statistically significant.

\section{Results}

\subsection{Distribution of Major Species}

Seaweed beds along the Chinese coast are dominated by Sargassum, Undaria, Porphyra, Gelidium, Scytosiphon, Hizikia, and Laminaria, including Sargassum muticum (Yendo) Fensholt, Sargassum confusum C.Agardh, Sargassum horneri (Turner.) C.Agardh, Laminaria japonica Areschoug, Undaria pinnatifida (Harvey) Suringar, Sargassum vachellianum Greville, Sargassum henslowianum C.Agardh, and Sargassum polycystum C.Agardh. The offshore water 
transparency of Liaoning and Shandong was greater than in Jiangsu and Zhejiang, and the seaweeds in these areas were the tallest. A list of the seaweeds we investigated is shown in Table A1.

Intertidal mudflats are an important component in the coastal waters of Jiangsu, and there are few seaweed resources. The offshore bedrock slopes in Zhejiang and Fujian are larger than elsewhere. Affected by the diluted water of the Yangtze River, the transparency is poor and the seaweed height is the lowest. Guangdong, Guangxi, and Hainan have smaller slopes along the coasts, and the seaweed beds have the largest distribution areas and abundance.

The mean biomass of the coastal seaweed beds in China was $7.29 \mathrm{~kg} / \mathrm{m}^{2}$, and the mean coverage was $41.25 \%$. Guangdong had the largest biomass of coastal seaweed resources, at $18,461.55 \mathrm{~g} / \mathrm{m}^{2}$, followed by Liaoning at $13,701.08 \mathrm{~g} / \mathrm{m}^{2}$. The mean coverage in the seaweed beds was $10-70 \%$, and the distances to the coastline were widely distributed from 5 to $300 \mathrm{~m}$. The coastal seaweed beds in Jiangsu had the smallest width at 5-10 m. The bathymetry of the seaweed beds gradually decreased from north to south, and the bathymetry of the coastal seaweed beds in Hainan was below $6 \mathrm{~m}$ (Table 2).

Table 2. Distribution of the seaweed beds along the Chinese coast.

\begin{tabular}{|c|c|c|c|c|c|c|c|}
\hline Region & $\begin{array}{c}\text { Mean } \\
\text { Biomass } \\
\left(\mathrm{g} / \mathrm{m}^{2}\right)\end{array}$ & $\begin{array}{c}\text { Thallus } \\
\text { Height }(\mathrm{cm})\end{array}$ & $\begin{array}{c}\text { Coverage } \\
(\%)\end{array}$ & $\begin{array}{l}\text { Distance } \\
\text { (m) }\end{array}$ & $\begin{array}{l}\text { Width } \\
\text { (m) }\end{array}$ & $\begin{array}{l}\text { Depth } \\
\text { (m) }\end{array}$ & Dominant Species \\
\hline Liaoning & $13,701.08$ & $9.8-518.8$ & $10-70$ & $15-100$ & $10-80$ & $\leq 14.98$ & $\begin{array}{l}\text { Sargassum muticum, } \\
\text { Sargassum confusum, } \\
\text { Undaria pinnatifida, } \\
\text { Laminaria japonica }\end{array}$ \\
\hline Shandong & 5755.43 & $9.4-414.2$ & $20-60$ & $5-300$ & 10-200 & $\leq 14.97$ & $\begin{array}{l}\text { Sargassum muticum, } \\
\text { Undaria pinnatifida, } \\
\text { Laminaria japonica }\end{array}$ \\
\hline Jiangsu & 1308.02 & $33.5-87.8$ & $10-40$ & $5-15$ & $5-10$ & $\leq 14.95$ & $\begin{array}{l}\text { Sargassum tenerrimum, } \\
\text { Ulva pertusa }\end{array}$ \\
\hline Zhejiang & 3845.24 & $12.1-207.0$ & $30-50$ & $5-40$ & $10-30$ & $\leq 14.99$ & $\begin{array}{l}\text { Sargassum vachellianum, } \\
\text { Sargassum horneri }\end{array}$ \\
\hline Fujian & 4005.955 & $12.5-161.5$ & $30-70$ & $5-50$ & $5-30$ & $\leq 12.05$ & $\begin{array}{l}\text { Sargassum vachellianum, } \\
\text { Sargassum horneri }\end{array}$ \\
\hline Guangdong & $18,461.55$ & $10.8-369.5$ & $20-50$ & $5-100$ & $5-40$ & $\leq 10.97$ & $\begin{array}{l}\text { Sargassum henslowianum } \\
\text { Sargassum hemiphyllum } \\
\text { var.chinense }\end{array}$ \\
\hline Guangxi & 7537.98 & 16.9-239.9 & $30-60$ & 10-200 & $10-40$ & $\leq 9.65$ & $\begin{array}{l}\text { Sargassum sanyaense, } \\
\text { Sargassumphyllocystum }\end{array}$ \\
\hline Hainan & 3732.15 & $6.0-240.0$ & $20-60$ & 10-200 & $5-40$ & $\leq 6.10$ & $\begin{array}{l}\text { Sargassum polycystum, } \\
\text { Sargassum emarginatum }\end{array}$ \\
\hline
\end{tabular}

Figure 2 shows the mean height and fresh weight distribution of the dominant seaweed species (Figure 2a) and Sargassum (Figure 2b) in the seaweed beds of China. As Figure 2a shows, from Liaoning to Hainan, the mean height and fresh weight of the dominant seaweed species in the seaweed beds showed decreasing trends as the latitude decreased. Liaoning had the largest mean height of $111.54 \pm 16.29 \mathrm{~cm}$, and Hainan had the smallest mean height of $50.46 \pm 4.62 \mathrm{~cm}$; the highest seaweed was the Sargassum muticum, Huang Jin Shan (HJS) $\left(38^{\circ} 47^{\prime} 30.29^{\prime \prime} \mathrm{N}, 121^{\circ} 16^{\prime} 10.55^{\prime \prime} \mathrm{E}\right)$, Liaoning, with a length of $518.5 \mathrm{~cm}$. 

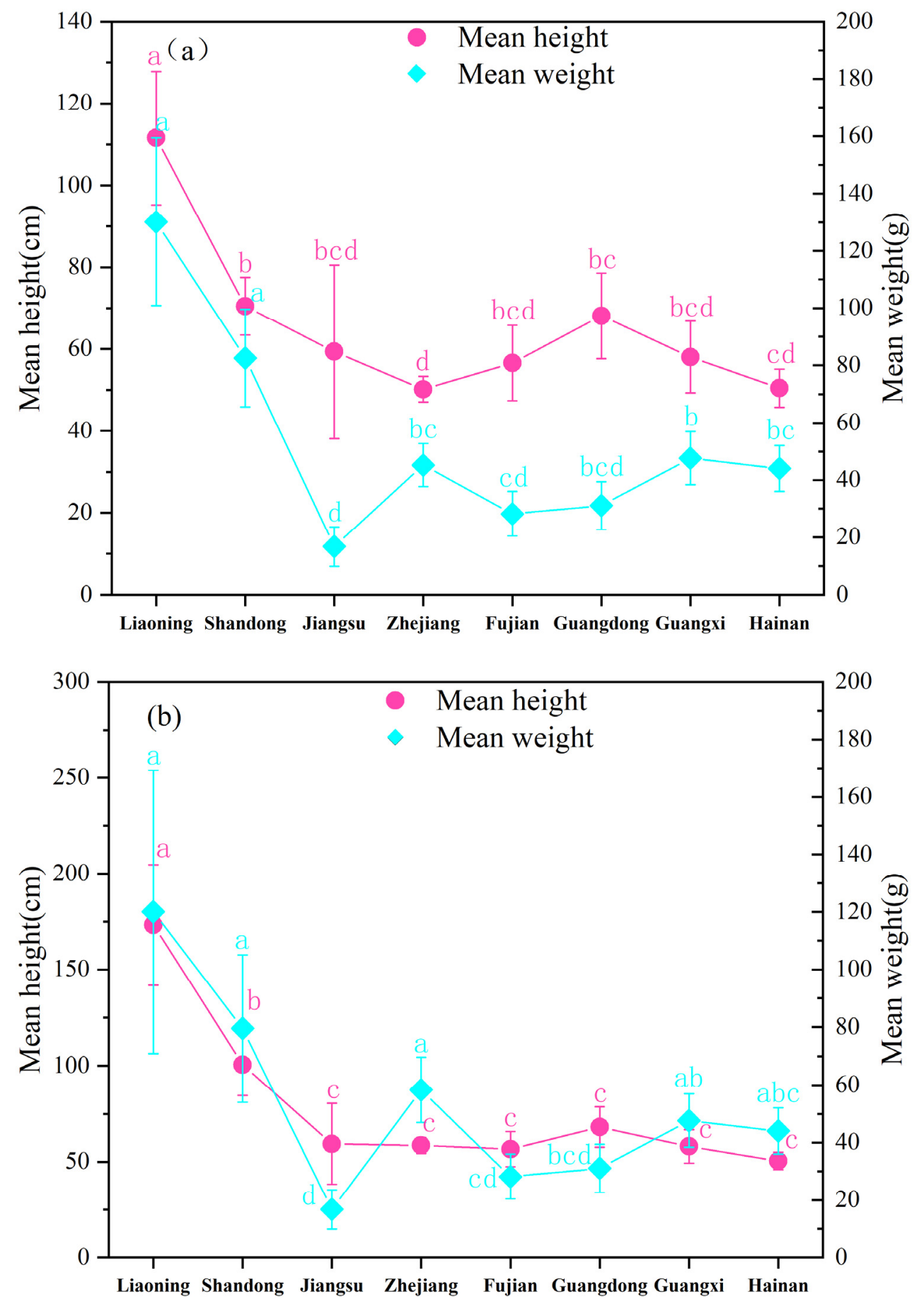

Figure 2. Distribution of the dominant species and Sargassum in seaweed beds. (a) Distribution of dominant seaweed species; (b) distribution of Sargassum. $(\mathrm{a}, \mathrm{b}, \mathrm{c}, \mathrm{d})$ indicate significant differences $(p<0.05)$.

The mean fresh weight in Liaoning was the largest, $130.14 \pm 29.26 \mathrm{~g}$, and the mean fresh weight in Jiangsu was the smallest, $16.74 \pm 6.84 \mathrm{~g}$. The mean height of the dominant species in Liaoning was significantly different from other regions, and there were no significant differences between Fujian and Guangxi. The mean weight in Jiangsu was significantly different from the other regions (Figure 2a). Among them, the height in the coastal seaweed beds of Zhejiang was lower than in the adjacent areas, but the mean fresh weight was larger compared with Jiangsu and Fujian. 
Figure $2 \mathrm{~b}$ shows the distributions of the mean height and fresh weight of Sargassum, which were widely distributed in the coastal waters of China. As seen in Figure 2b, from north to south, the mean height and fresh weight of Sargassum also showed a decreasing trend with the decrease in latitude. The mean height and fresh weight of Sargassum in the coastal seaweed beds of Liaoning were the largest, being $173.22 \pm 31.39 \mathrm{~cm}$ and $120.01 \pm 49.18 \mathrm{~g}$, respectively.

The mean height of Sargassum was the smallest in Hainan at $50.46 \pm 4.62 \mathrm{~cm}$, and the mean fresh weight in Jiangsu was the smallest at $16.74 \pm 6.84 \mathrm{~g}$. The mean weight of Sargassum in Jiangsu was significantly different from the other regions. Apart from Liaoning and Shandong, there were no significant differences in the mean height of Sargassum (Figure 2b).

Among the dominant species in the seaweed beds, Undaria pinnatifida and Laminaria japonica were the most abundant seaweeds along the coasts of the Yellow Sea and the northern part of the East China Sea. Sargassum muticum is a temperate species, and it was distributed from Da Hao Zi Dao (DHZD) to Tai Ping Jiao (TPJ). Sargassum horneri is a warm temperate species, and it was distributed from DHZD to Ping Tan Xian (PTX) near the coast (Figure 3). For the mean height of Undaria pinnatifida, a significant difference was revealed in DHZD compared with the other sites (Figure 3a).

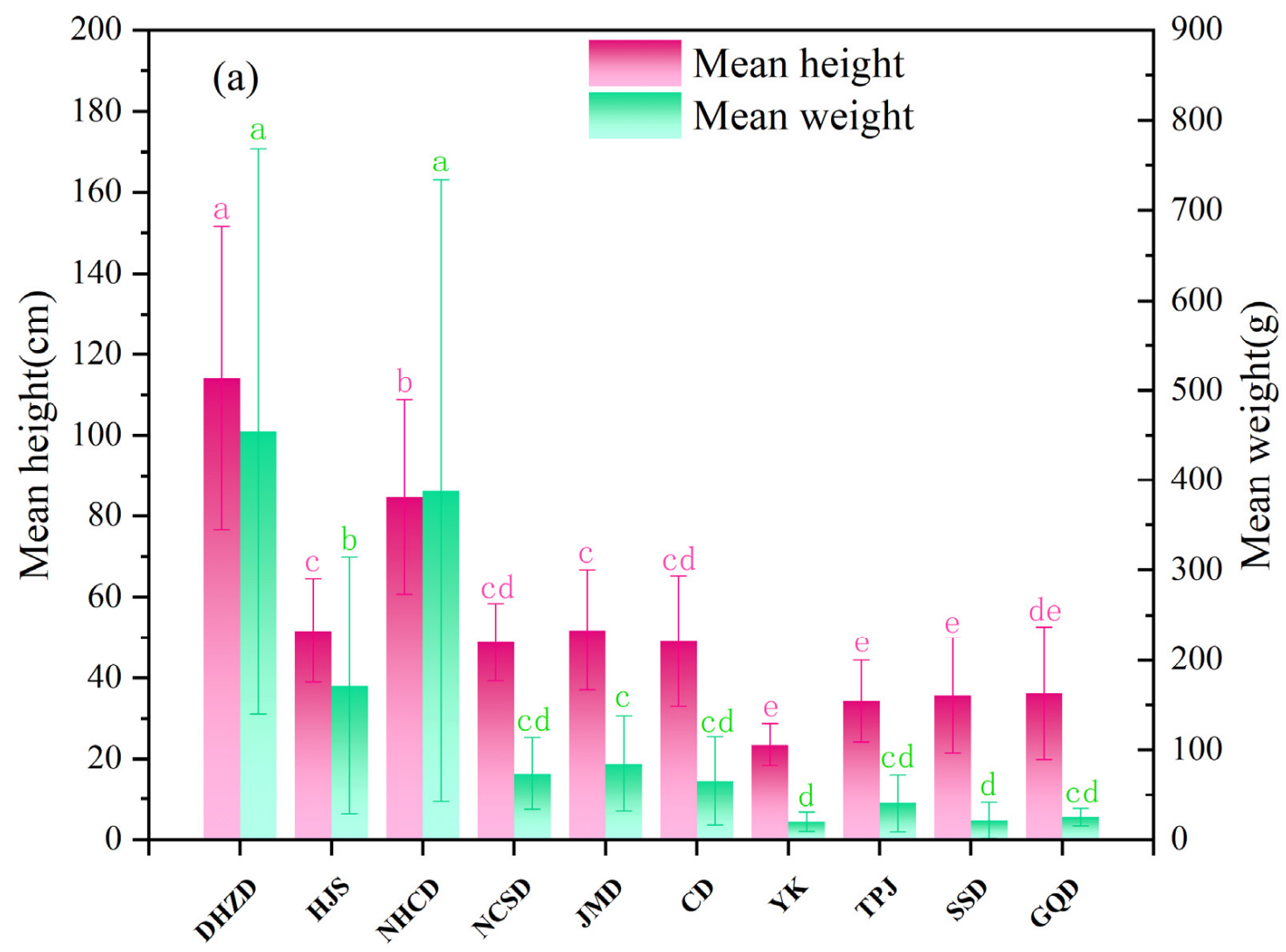

Figure 3. Cont. 

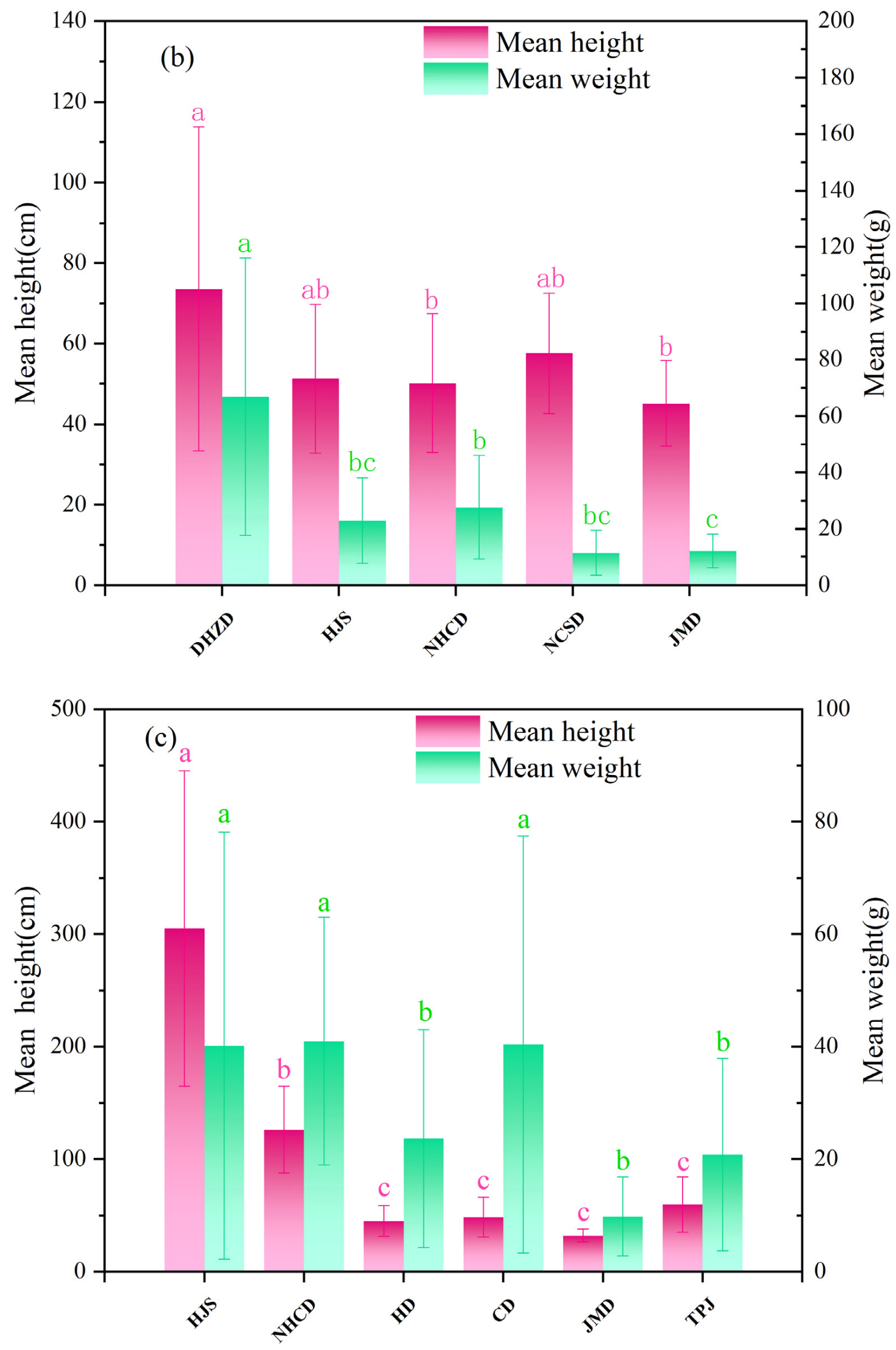

Figure 3. Cont. 


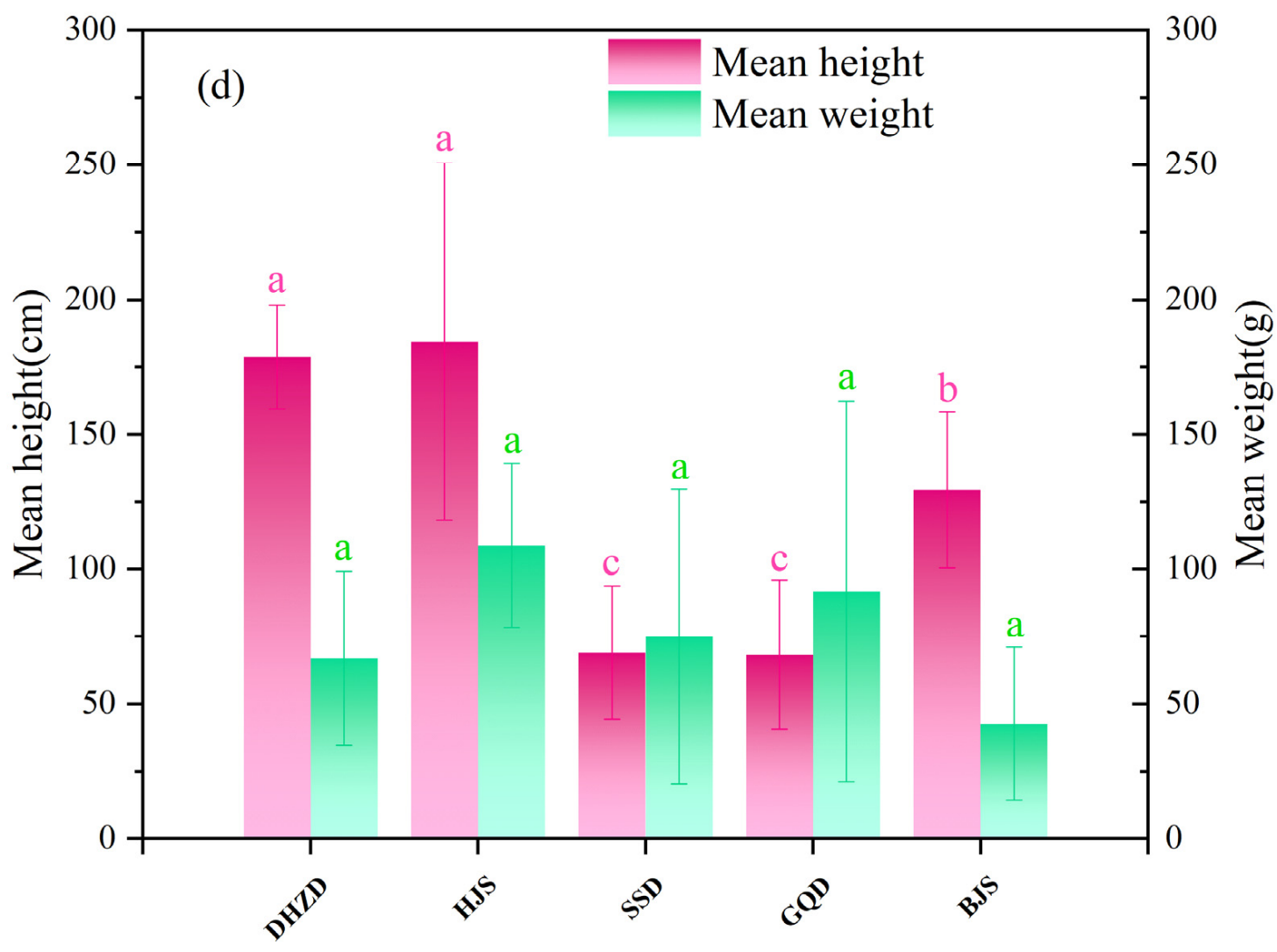

Figure 3. The distributions of four dominant species: (a) Undaria pinnatifida, (b) Laminaria japonica, (c) Sargassum muticum, and (d) Sargassum horneri. $(\mathrm{a}, \mathrm{b}, \mathrm{c}, \mathrm{d})$ indicate significant differences $(p<0.05)$.

The mean weight of Laminaria japonica in DHZD was significantly different from the other sites (Figure 3b). There were no significant differences in the mean height of Sargassum muticum from among the sites at Hui Dao (HD), Chu Dao (CD), Ji Ming Dao (JMD), and TPJ (Figure 3c). The mean height of Sargassum horneri in Bi Jia Shan (BJS) was significantly different from the other sites, and there were no significant differences in the mean weight of Sargassum horneri from among the sites at DHZD, HJS, Sheng Shan Dao (SSD), Gou Qi Dao (GQD), and BJS (Figure 3d). From north to south, the mean height and fresh weight of Undaria pinnatifida, Laminaria japonica, and Sargassum muticum showed decreasing trends as the latitude decreased.

\subsection{Dominant Species in Seaweed Beds}

Seaweed beds are composed of a fixed number and size of marine macroalgae, with particular community characteristics and relatively stable ecological habits [27]. In the species composition of seaweed beds, certain dominant species have more biomass, are widely distributed, and have regional representation. However, some species are distributed in small numbers, as minor or even as rare species, as they have not yet settled and thrived. Therefore, these species cannot be viewed as the representative species for the division of the seaweed bed flora in this region. Therefore, in the process of dividing the seaweed beds, whether one species is representative of the flora mainly depends on the height, biomass, density, and distribution scale.

Sargassum, Laminaria, and Undaria are the abundant seaweeds in the coastal waters of China, being taller, of greater biomass, and more widespread (Table 3). The mean height of Sargassum muticum was $131.98 \mathrm{~cm}$, which was the largest. The second largest was Sargassum henslowianum at $125.81 \mathrm{~cm}$. The seaweed with the lowest height was Sargassum hemiphyllum var.chinense at $28.48 \mathrm{~cm}$. The mean fresh weights of Sargassum confusum, 
Sargassum tenerrimum, Sargassum phyllocystum, and Sargassum emarginatum were more than $100 \mathrm{~g}$, while the mean fresh weight of Sargassum graminifolium was the lowest at $8.27 \mathrm{~g}$.

Table 3. The characteristics of the dominant species in seaweed beds of China.

\begin{tabular}{|c|c|c|c|c|}
\hline Species & $\begin{array}{l}\text { Temperature } \\
\text { Property }\end{array}$ & Mean Height (cm) & $\begin{array}{l}\text { Mean Fresh } \\
\text { Weight (g) }\end{array}$ & Regression Equation \\
\hline Sargassum horneri & WT & 91.05 & 98.62 & $Y=0.7172 x^{1.0349}\left(R^{2}=0.8147^{* *}\right)$ \\
\hline Sargassum vachellianum & ST & 44.58 & 23.11 & $Y=0.7196 x^{0.8964}\left(R^{2}=0.6605^{*}\right)$ \\
\hline Sargassum muticum & WT & 131.98 & 63.14 & $Y=0.3313 x^{1.0435}\left(R^{2}=0.8668^{* *}\right)$ \\
\hline Sargassum confusum & WT & 95.00 & 185.17 & $Y=0.0350 x^{1.8481}\left(R^{2}=0.7550^{* *}\right)$ \\
\hline Undaria pinnatifida & WT & 46.83 & 93.68 & $Y=0.1173 x^{1.6995}\left(R^{2}=0.9017^{* *}\right)$ \\
\hline Laminaria japonica & $\mathrm{CT}$ & 61.16 & 42.80 & $Y=0.0471 x^{1.6272}\left(R^{2}=0.9131^{* *}\right)$ \\
\hline Sargassum tenerrimum & - & 59.30 & 167.34 & $Y=0.6105 x^{1.3491}\left(R^{2}=0.7508^{* *}\right)$ \\
\hline Sargassum graminifolium & - & 29.82 & 8.27 & $Y=0.2038 x^{1.0657}\left(R^{2}=0.8853^{* *}\right)$ \\
\hline $\begin{array}{l}\text { Sargassum } \\
\text { henslowianum }\end{array}$ & - & 125.81 & 70.79 & $Y=0.3936 x^{1.0097}\left(R^{2}=0.7068^{* *}\right)$ \\
\hline $\begin{array}{l}\text { Sargassum hemiphyllum } \\
\text { var.chinense }\end{array}$ & WT & 28.48 & 10.44 & $Y=0.5907 x^{0.8179}\left(R^{2}=0.9128^{* *}\right)$ \\
\hline Sargassum sanyaense & - & 34.85 & 51.84 & $Y=0.0808 x^{1.7733}\left(R^{2}=0.9737^{* *}\right)$ \\
\hline Sargassum fulvellun & - & 63.04 & 108.19 & $Y=0.0122 x^{2.1498}\left(R^{2}=0.881^{* *}\right)$ \\
\hline Sargassum polycystum & - & 54.29 & 33.35 & $Y=0.2434 x^{1.2067}\left(R^{2}=0.9305^{* *}\right)$ \\
\hline Sargassum emarginatum & - & 80.58 & 122.95 & $Y=0.3219 x^{1.3615}\left(R^{2}=0.8015^{* *}\right)$ \\
\hline Sargassum swartzii & $\operatorname{Tr}$ & 41.66 & 51.72 & $Y=0.0101 x^{2.2237}\left(R^{2}=0.9384^{* *}\right)$ \\
\hline
\end{tabular}

(1) CT—cold temperate; WT—warm temperate; ST—subtropical; Tr—tropical; (2) Y—fresh weight of seaweeds; $x$-thallus height of seaweeds. "***" and "**" represent significant difference at the level of 0.01 and 0.05 , respectively.

Among the most abundant species, Laminaria and Undaria dominated the coast of Liaoning and Shandong. Sargassum was widely distributed along the Chinese coast. The amount of Sargassum was characterized by more in the south and less in the north. The species of Sargassum were most abundant along the South China Sea coast, with 124 species accounting for $36.47 \%$ of the total, followed by the East China Sea (13 species of Sargassum) and the Yellow Sea and the Bohai Sea (10 species of Sargassum). Among these areas, 78 species of Sargassum in the subtidal zone were recorded [28].

The regression equation in Table 3 shows the fitting relationship between the seaweed fresh weight and the height of each species; from this we can see that the relationship between the height and fresh weight was a power function-the fresh weight of seaweed increased with height. The equation fit well. According to Pearson's test, except for Sargassum vachellianum, most of them were significantly correlated at the level of 0.01 .

\subsection{Types of Seaweed Beds}

The flora types of seaweed beds reflect the affinities and similarities of the flora among different regions. The traditional method of dividing seaweed flora according to the classification characteristics of seaweeds mainly reflects the stable difference and development of seaweed species; the analysis of the characteristics of the dominant species can reflect the fauna more clearly [29]. In the coastal waters of China, from Liaoning to Jiangsu, the seawater temperature is likely to belong to the temperate zone; these waters are dominated by warm temperate species, such as Sargassum muticum and Sargassum confusum, with a mean biomass of $6921.51 \mathrm{~g} / \mathrm{m}^{2}$.

Among these species, in the offshore area of Jiangsu, the sediment types mainly include silty sand and muddy sand, and only along the coast of Che Niu Shan Dao (CNSD) was there a small amount of Sargassum tenerrimum. The shore from Zhejiang to Guangxi belongs to the warm water zone and is dominated by subtropical species, such as Sargassum vachellianum, with a mean biomass of $8462.68 \mathrm{~g} / \mathrm{m}^{2}$. The maximum mean biomass $\left(3732.15 \mathrm{~g} / \mathrm{m}^{2}\right)$ was found in the coastal areas of Hainan. 
In the offshore area of Jiangsu, the sediment types mainly included silty sand, and Sargassum tenerrimum was distributed only along the coast of CNSD, with a smaller height $(30-80 \mathrm{~cm})$. In addition, the coastal waters of Jiangsu are always affected by the Yangtze River current, which restricts the migration of seaweed from north to south. Therefore, we classified the region into the same type as Liaoning and Shandong. Guangxi has many coastal bays and estuaries and is the transition area of subtropical to tropical, featuring mostly subtropical species; the diversity of species of Sargassum along the coast of Hainan was quite different. Therefore, it was classified into the same type as Guangdong and the north (Figure 4).

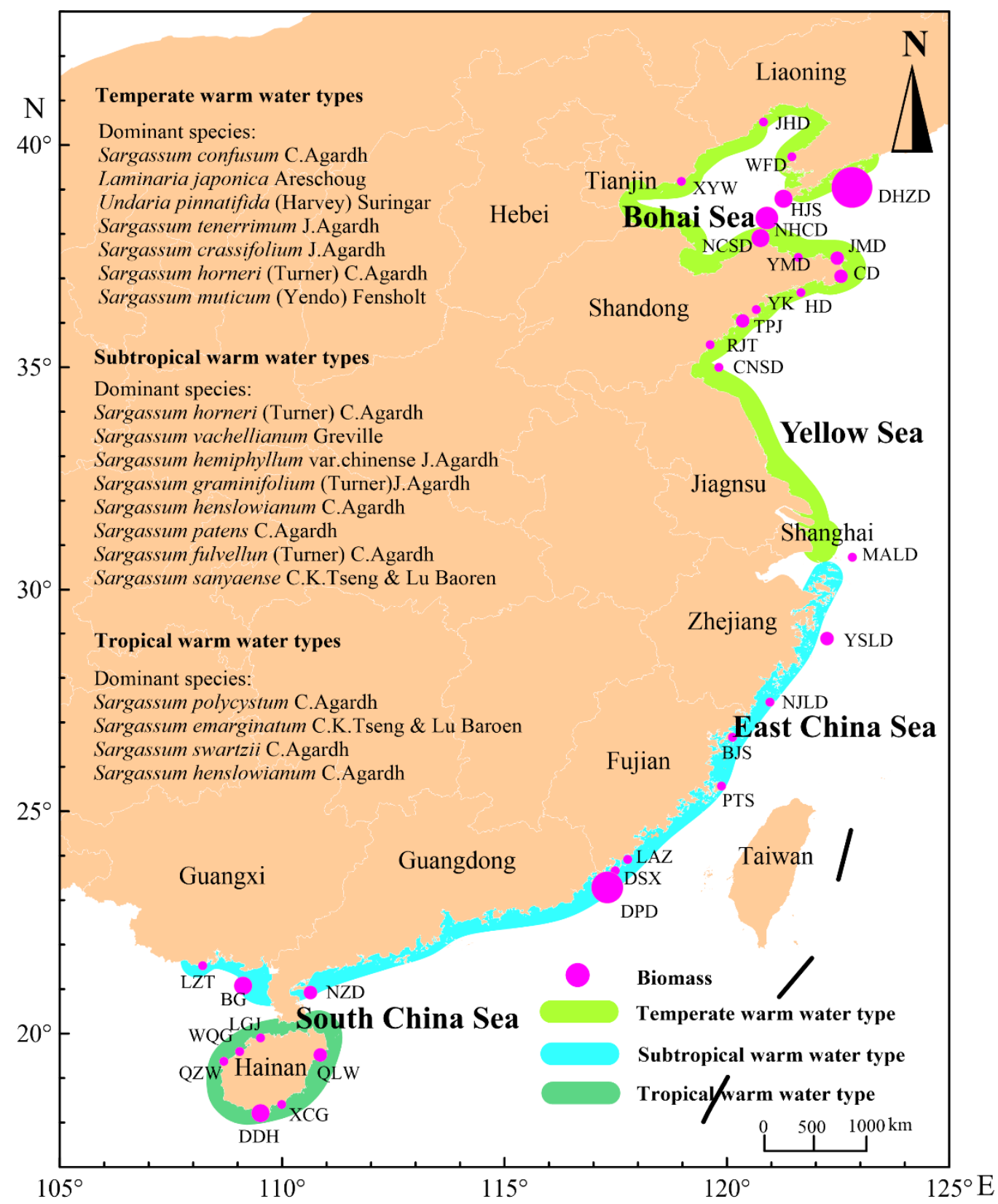

Figure 4. Characteristics of the dominant species in different types of seaweed beds.

Based on the historical research of Tseng (1959) and Chang (1996) on seaweed flora [22,30], combined with water temperature, the composition of seaweed species, and the characteristics of dominant species in the coastal waters of China, Chinese seaweed beds can 
be divided into three types: temperate warm water types, subtropical warm water types, and tropical warm water types.

Temperate warm water types are mainly distributed on the coasts of the Bohai Sea and the Yellow Sea, where the water temperature in winter is $0-6{ }^{\circ} \mathrm{C}$ and in summer $26-27^{\circ} \mathrm{C}$. The regions include Liaoning, Hebei, Tianjin, Shandong, Jiangsu, and Shanghai. Typical seaweed beds primarily include Sargassum horneri and Laminaria japonica beds along the coast of DHZD, Liaoning; Sargassum confusum and Sargassum muticum beds along the coast of HJS, Liaoning; Laminaria japonica and Sargassum muticum beds in the offshore area of Nan Huang Cheng Dao (NHCD), Shandong; and Laminaria japonica and Undaria pinnatifida beds along the coast of JMD, Shandong.

Subtropical warm water types were mainly distributed along the coast of the East China Sea and the northern coast of the South China Sea, where the water temperature in winter is $7-19{ }^{\circ} \mathrm{C}$ and in summer $27-29^{\circ} \mathrm{C}$. The regions include Zhejiang, Fujian, Guangdong, and Guangxi. Typical seaweed beds mainly include Sargassum vachellianum and Sargassum horneri beds along the coast of Ma An Lie Dao (MALD, include SSD, BXD, LHD, SHS, HND, GQD), Zhejiang; Sargassum hemiphyllum var.chinense beds in the offshore area of Dong Shan Xian (DSX), Fujian; Sargassum henslowianum beds along the coast of Ding Peng Dao (DPD), Guangdong; and Sargassum hemiphyllum and Sargassum sanyaense beds along the coast of Bei Gang (BG), Guangxi.

Tropical warm water types were mainly distributed along the southern coast of the South China Sea, where the water temperature in winter is $20-29^{\circ} \mathrm{C}$ and in summer more than $29^{\circ} \mathrm{C}$. The region involved is Hainan. Typical seaweed beds mainly include Sargassum polycystum beds along the coast of Qing Lan Wan (QLW); Sargassum emarginatum beds along the coast of DDH; and Sargassum polycystum and Sargassum swartzii beds along the coast of Qi Zi Wan (QZW).

\section{Discussion}

\subsection{Distribution of Seaweed Beds}

The occurrence and development of seaweed are the results of long-term development under a specific environment [31]. Seaweed beds not only have local species but also exotic species introduced by human activities, ocean currents, and other factors. Due to the influences of certain factors, such as shoreline riverside and geological changes, the distributions of some species can appeared to be discontinuous or patchy, and long-term geographic isolation can lead to new species, which ultimately lead to a change in the composition of seaweed beds [32].

The geographical distribution of seaweed beds is mainly affected by water temperature and sediment conditions [10,33-35]. With the latitude decreasing from north to south along the coasts of the seas of China, the cold-water species, such as Laminaria japonica, quickly disappeared, and warm-water species increased gradually. In the western part of the Bohai Bay in Liaoning and along the coast of Jiangsu, the sediment types mainly included silty sand, and the seaweed resources were lower than in other places. The seaweed beds in Jiangsu were only distributed in CNSD, with a biomass of $1308.02 \mathrm{~g} / \mathrm{m}^{2}$.

The coastal waters of Shanghai are affected by the runoff of the Yangtze River, with lower salinity and transparency, which is detrimental to the growth of seaweeds [36]. The mean height $(50.19 \pm 3.12 \mathrm{~cm})$ along the coast of Zhejiang was smaller than that of the adjacent Jiangsu $(59.33 \pm 21.17 \mathrm{~cm})$ and Fujian areas $(56.56 \pm 9.20 \mathrm{~cm})$. However, the mean biomass was larger-the reasons for this may partly involve the fact that the transparency of the water is poor, and thus the seaweeds increase the biomass of their organs, such as fronds and pneumatocysts, through auto-regulation to balance the photosynthetic rate required for their growth.

The dominant genus in the seaweed beds of China is Sargassum, followed by Undaria and Laminaria. Seaweed beds are distributed in patches along the coast of China-this result is in accordance with Tseng (1959) on the discontinuity of the distribution of Sargassum [22]. 
Typically, seaweeds of Sargassum in seaweed beds were distributed along the side of the reef surface in the subtidal zone.

However, in Wen Qing Gou (WQG) in Hainan and BG in Guangxi there were many coral reefs along the coast, and the distribution pattern of Sargassum was in clusters. Liao (2016) suggested that there were some competitive and coordination relationships between seaweeds and coral reefs; however, the particular mechanism of influence on the distribution of seaweeds needs to be explored in the future $[37,38]$.

The coastal waters of Zhejiang, Fujian, and Guangdong mainly belong to the warm water zone. The dominant species in these regions are mainly subtropical species. There is a possibility that Taiwan's warm currents transport the sporophytes from the south to the north $[30,39]$. Correspondingly, seaweed beds formed by the cold-water species, Laminaria japonica, rarely migrate southward along the coast. This may be due to a lack of rock shores that are suitable for sporophyte fixation in the coastal waters of Jiangsu; another reason is the hindering effect of the Yangtze River.

\subsection{Seaweed Beds' Flora}

The distribution of seaweeds in one place is mainly affected by water temperature, light intensity, surface currents, and other factors. This distribution is a long-term product of the history and geography of the nearshore area. Its characteristics are mainly reflected in the composition and natural distribution of dominant species. Therefore, the temperature attribute of seaweed beds is the coupling temperature of all species there [34,40].

Over time, the composition of species in the seaweed beds changes to some degree, with the rise of geographical variants and even new species. Therefore, species preferring different temperatures arise regardless of the local temperature-for instance, sub-frigid or even frigid species can develop in the cold temperate zone [41]. Tseng (1959) used geography, the experimental biology of algae, and specimen analysis methods to divide seaweeds into the following categories: (1) cold-water species (suitable temperature for growth and reproduction $\left.<4{ }^{\circ} \mathrm{C}\right)$; (2) temperate-water species $\left(4^{\circ} \mathrm{C} \leq\right.$ suitable temperature $\leq 20^{\circ} \mathrm{C}$ ); and (3) warm-water species (suitable temperature $>20^{\circ} \mathrm{C}$ ) [22].

Research has shown that seaweed species along the coasts of the Yellow Sea and the Bohai Sea in China have temperate water properties, while there are very few cold-water species $(6 \%)$ [34,42]. The East China Sea is still dominated by warm temperate species, with few cold temperate species, while the south has some subtropical species and no cold-water species [22]. Warm-water species are the abundant seaweeds in the coastal waters of the South China Sea, where subtropical species are dominant, and tropical species dominate on the southern coast [43].

Since the 1950s, seaweed researchers represented by Tseng have established flora divisions of seaweeds along the coast of China. Specifically, these divisions are the western Yellow Sea (including the Bohai Sea), the western East China Sea, the northern South China Sea, and the southern South China Sea [22]. Regarding the distribution of Sargassum, Huang (2013) believed that the difference between the western part of the Yellow Sea and the western part of the East China Sea was not obvious and suggested that the two should be merged.

Sargassum flora in China were then divided into two regions-one is the west of the Yellow Sea and East China Sea; the other is the South China Sea area [28]. In our survey, based on the ecological characteristics of the dominant species in seaweed beds, Laminaria japonica and Undaria pinnatifida were widely distributed along the coast of Liaoning and Shandong. Along Zhejiang and the southern coast, seaweed beds formed by Laminaria japonica were rarely found.

This study presented evidence for the conclusion that, based on the feature attributes of the dominant species and seawater temperature attributes, the seaweed beds along the coast of the Bohai Sea and the Yellow Sea are temperate warm water types, whilst from the East China Sea to the southern Guangxi, they are subtropical warm water types; 
the seaweed beds along the coast of the southern part of the South China Sea were defined as tropical warm water types.

Zhang (1996) systematically compared the distributions of 835 species of seaweeds along the coast of China by analyzing the characteristics and genetic relationships of the seaweed in each marine area, using the Jaccard index to judge the seaweed properties, and concluded that the similarity coefficients of Zhejiang, Fujian, and Guangdong were all greater than 0.5 [30]. This indicated that they are closely related. Xiang (2002) stated that subtropical species are distributed along the coast of Zhejiang, accounting for $69.2 \%$ of the total species, with this region thus belonging to the subtropical zone [36]. Both viewpoints are in accordance with the standpoint that seaweed beds along the coast of Zhejiang, Fujian, and Guangdong are united as subtropical warm water types, as suggested in this study.

\section{Conclusions}

Sargassum in seaweed beds were found to be the most abundant seaweeds along the coast of China, followed by Undaria and Laminaria. Seaweed beds with Laminaria japonica and Undaria pinnatifida as the dominant species were mainly distributed along the coast of Liaoning and Shandong.

The mean biomass of seaweed beds in China was $7.29 \mathrm{~kg} / \mathrm{m}^{2}$ and their mean coverage was $41.25 \%$. From north to south, the mean height and fresh weight of the dominant species gradually decreased with decreasing latitude. The mean fresh weights of the dominant species in seaweed beds along the Jiangsu coasts were the smallest (16.74 $\pm 6.84 \mathrm{~g})$. The bathymetry of the seaweed beds gradually decreased from north to south and was lowest in Hainan, at $6 \mathrm{~m}$ or less.

Based on the seawater temperature, the dominant species in the seaweed beds, and the dominant species' distribution characteristics, the seaweed beds in China can be defined as follows: along the coast from Liaoning to Shanghai, the seaweed beds are temperate warm water types; along the coast from Zhejiang to Guangxi, the seaweed beds are subtropical warm water types; and along the coast of the South China Sea and southward, the seaweed beds are tropical warm water types.

The government should, therefore, make the ranking of seaweed beds a priority in order to implement protective measures according to the types of seaweed beds and coastal germplasm resources, while the distribution range of seaweed can be defined according to the ecological properties of the target species.

Author Contributions: Conceptualization, X.L. and S.Z.; methodology, K.W., S.Z. and M.F.; software, X.L.; validation, K.W., S.Z and M.F.; formal analysis, X.L. and K.W.; investigation, X.L., K.W. and S.Z.; resources, S.Z.; data curation, X.L.; writing-original draft preparation, X.L.; writing-review and editing, S.Z. and K.W.; visualization, X.L. and M.F.; supervision, S.Z.; project administration, K.W. and S.Z.; funding acquisition, S.Z. All authors have read and agreed to the published version of the manuscript.

Funding: This research was funded by China Agriculture Research System (CARS-50).

Institutional Review Board Statement: Not applicable.

Informed Consent Statement: Not applicable.

Data Availability Statement: Not applicable.

Acknowledgments: We greatly appreciate the support of our funding agency: China Agriculture Research System (CARS-50). We also acknowledge Zhenhua Wang, Xiaopeng Cheng, Huiming Jia, Yifan Chen, Jian Zhang, Yuan Lin, and Jianqu Chen for their support and comments during the production of this article.

Conflicts of Interest: The authors declare no conflict of interest. 


\section{Appendix A}

A list of the seaweeds we investigated is shown in Table A1.

Table A1. The seaweeds investigated.

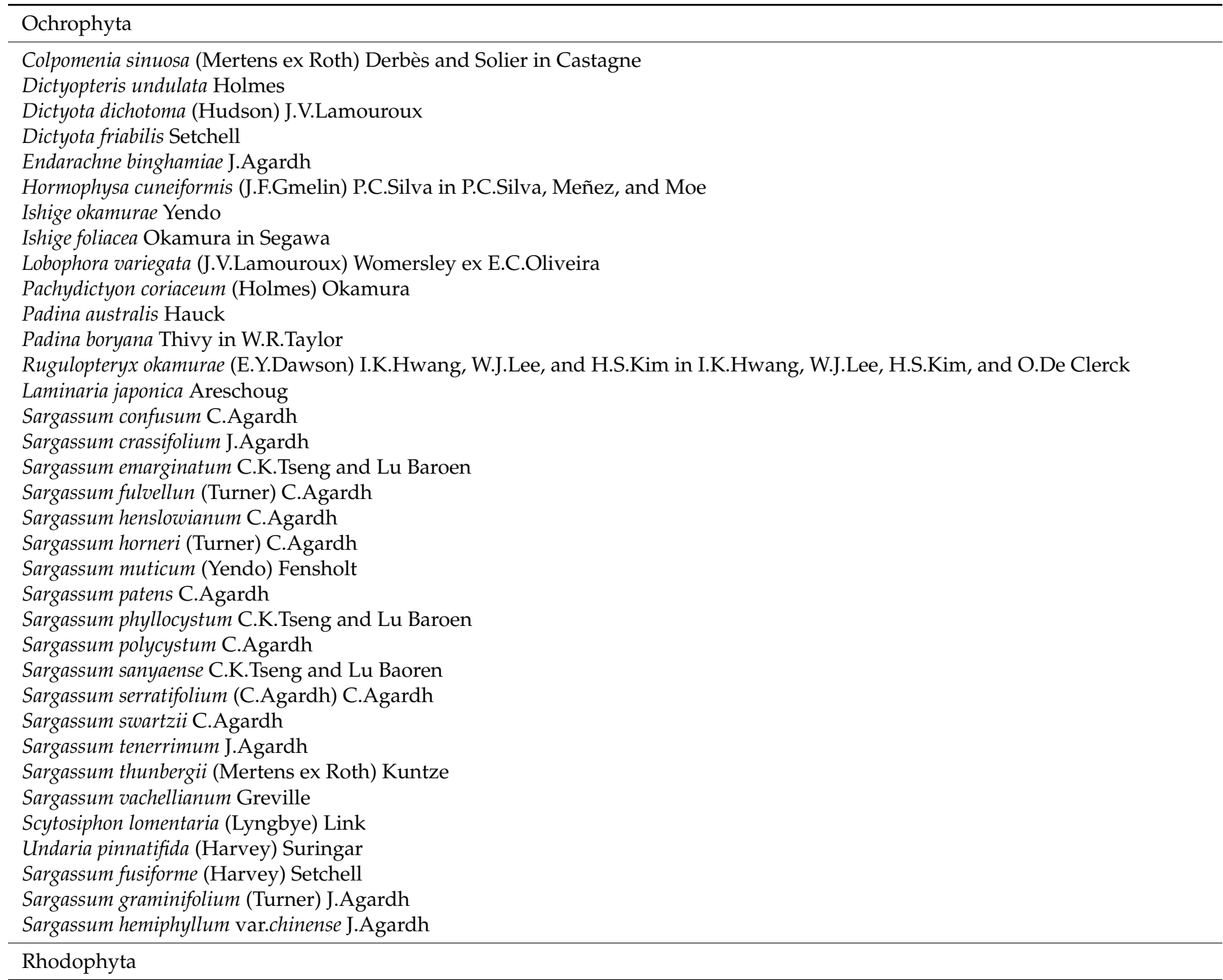

Gigartina intermedia Suringar

Laurencia pinnata Yamada

Polysiphonia japonica Harvey in M.C. Perry

Acrosorium yendoi Yamada

Ahnfeltiopsis flabelliformis (Harvey) Masuda

Amphiroa dilatata J.V.Lamouroux

Amphiroa ephedraea (Lamarck) Decaisne

Amphiroa ephedraea (Lamarck) Decaisne

Calliarthron yessoense (Yendo) Manza

Callophyllis adhaerens Yamada

Ceramium japonicum Okamura

Chondria crassicaulis Harvey

Chondria tenuissima var. minuta C.Agardh

Chondrus nipponicus Yendo

Chondrus ocellatus Holmes

Corallina officinalis Linnaeus

Gelidium amansii (J.V.Lamouroux) J.V.Lamouroux

Gelidium yamadae K.-C.Fan

Gigartina intermedia Suringar 
Table A1. Cont.

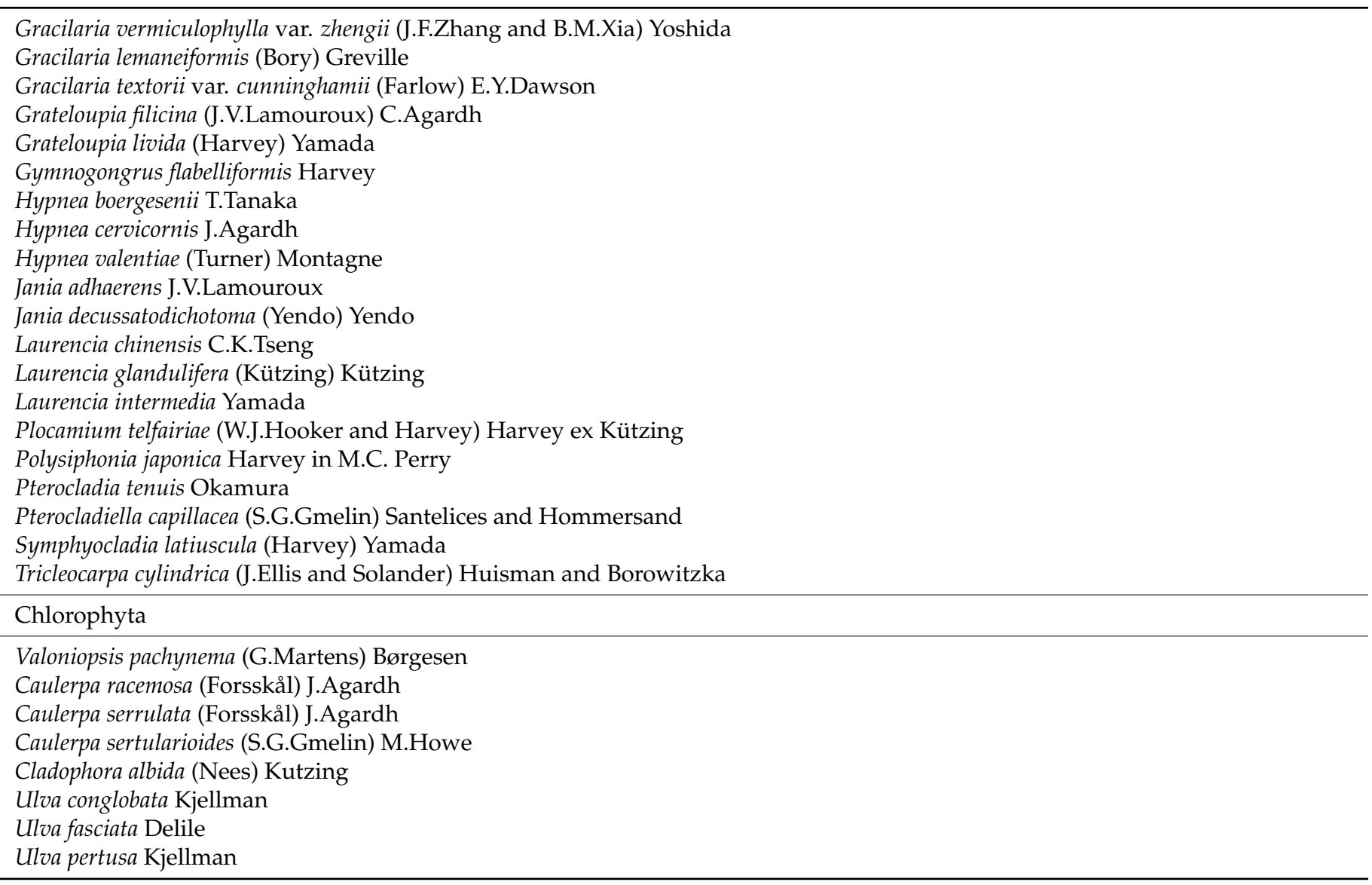

\section{References}

1. Kang, C.K.; Choy, E.J.; Son, Y.; Lee, J.Y.; Kim, J.K.; Kim, Y.; Lee, K.S. Food web structure of a restored macroalgal bed in the eastern Korean peninsula determined by C and N stable isotope analyses. Mar. Biol. 2008, 153, 1181-1198. [CrossRef]

2. Al, M.A.; Akhtar, A.; Rahman, M.F.; Kamal, A.H.M.; Karim, N.U.; Hassan, M.L. Habitat structure and diversity patterns of seaweeds in the coastal waters of Saint Martin's Island, Bay of Bengal, Bangladesh. Reg. Stud. Mar. Sci. 2020, 33, 1-10.

3. Jiang, R.J.; Zhang, S.Y.; Bi, Y.X.; Wang, Z.H.; Zhou, X.J.; Zhao, X.; Chen, L.R. Food sources of small invertebrates in the macroalgal bed of Gouqi Island. J. Fish. China 2015, 39, 1487-1498.

4. Edgar, G.J.; Aoki, M. Resource limitation and fish predation: Their importance to mobile epifauna associated with Japanese Sargassum. Oecologia 1993, 95, 122-133. [CrossRef] [PubMed]

5. Graham, M.H. Effects of Local Deforestation on the Diversity and Structure of Southern California Giant Kelp Forest Food Webs. Ecosystems 2004, 7, 341-357. [CrossRef]

6. Harley, C.D.G.; Anderson, K.M.; Demes, K.W.; Jorve, J.P.; Kordas, R.L.; Coyle, T.A.; Graham, M.H. Effects of climate change on global seaweed communities. J. Phycol. 2012, 48, 1-15. [CrossRef]

7. Teagle, H.; Hawkins, S.J.; Moore, P.J.; Smale, D.A. The role of kelp species as biogenic habitat formers in coastal marine ecosystems. J. Exp. Mar. Biol. Ecol. 2017, 492, 81-98. [CrossRef]

8. Mauffrey, A.R.L.; Cappelatti, L.; Griffin, J.N.; Saha, M. Seaweed functional diversity revisited: Confronting traditional groups with quantitative traits. J. Ecol. 2020, 108, 2390-2405. [CrossRef]

9. Wang, Y.; Lyu, D.W.; Tian, Y.; Wang, X.M. Effect of large seaweed, seagrass on marine ecological aquaculture and its application in marine ranching. Hubei Agric. Sci. 2020, 59, 125-128.

10. Zhang, S.Y.; Liu, S.R.; Zhou, X.J.; Wang, Z.H.; Wang, K. Ecological function of seaweed-formed habitat and discussion of its application to sea ranching. J. Fish. China 2019, 43, 2005-2014.

11. Gao, Y.; Lin, G.H. Algal diversity and their importance in ecological processes in typical mangrove ecosystems. Biodivers. Sci. 2018, 26, 1223-1235. [CrossRef]

12. Wu, Z.L.; Cui, X.S.; Tang, F.H.; Xiong, M.S. Research on genecology of benthic macroalgae. Fish. Inf. Strategy 2018, 33, 37-44. 
13. Terada, R.; Abe, M.; Abe, T.; Aoki, M.; Dazai, A.; Endo, H.; Kamiya, M.; Kawai, H.; Kurashima, A.; Motomura, T.; et al. Japan's nationwide long-term monitoring survey of seaweed communities known as the "Monitoring Sites 1000": Ten-year overview and future perspectives. Phycol. Res. 2019, 69, 12-30. [CrossRef]

14. Raybaud, V.; Beaugrand, G.; Goberville, E.; Delebecq, G.; Destombe, C.; Valero, M.; Davoult, D.; Morin, P.; Gevaert, F. Decline in kelp in West Europe and climate. PLoS ONE 2013, 8, 1-10.

15. Dexter, K.F.; Wernberg, T. Rise of Turfs: A new battlefront for globally declining kelp forests. Bioscience 2018, 68, 64-76.

16. Tanaka, K.; Taino, S.; Haraguchi, H.; Prendergast, G.; Hiraoka, M. Warming off southwestern Japan linked to distributional shifts of subtidal canopy-forming seaweeds. Ecol. Evol. 2012, 2, 2854-2865. [CrossRef] [PubMed]

17. Bell, T.W.; Allen, J.G.; Cavanaugh, K.C.; Siegel, D.A. Three decades of variability in California's giant kelp forests from the Landsat satellites. Remote Sens. Environ. 2020, 238, 1-13. [CrossRef]

18. Gower, J.F.R.; King, S.A. Distribution of floating Sargassum in the Gulf of Mexico and the Atlantic Ocean mapped using MERIS. Int. J. Remote Sens. 2011, 32, 1917-1929. [CrossRef]

19. Santelices, B. The discovery of kelp of rests in deep-water habitats of tropical regions. Natl. Acad. Sci. 2007, 104, 19163-19164. [CrossRef]

20. Starko, S.; Smyth, C.; Kucera, H. Attachment strength of the herbivorous rockweed isopod, Idotea wosnesenskii (Isopoda, Crustaceae, Arthropoda), depends on properties of its seaweed host. J. Exp. Mar. Biol. Ecol. 2016, 477, 1-6. [CrossRef]

21. Setchell, W.A. The temperature interval in the geographical distribution of marine algae. Science 1920, 52, 187-190. [CrossRef]

22. Tseng, C.K.; Chang, C.F. On the regional division of the marine algal flora of the Western North Pacidic. Oceanol. Limnol. Sin. 1959, 2, 244-267.

23. Araujo, R.M.; Bartsch, I.; Bekkby, T.; Erzini, K.; Pinto, I.S. What is the impact of kelp forest density and/or area on fisheries? Environ. Evid. 2013, 2, 1-4. [CrossRef]

24. Denis, V.; Chen, C.A.; Song, J.I.; Woo, S. Alveopora japonica beds thriving under kelp. Coral Reefs 2013, 32, 503. [CrossRef]

25. Allen, J.C.; Griffiths, C.L. The fauna and flora of a kelp bed canopy. S. Afr. J. Zool. 2015, 16, 80-84. [CrossRef]

26. Zhang, S.Y.; Cui, X.; Wang, Z.H.; Wang, K.; Cheng, X.P.; Liu, S.R.; Shen, H. Community structure of epiphytic macroalgae on mussel cultured rafts in Gouqi Island. J. Fish. China 2020. Available online: https://kns.cnki.net/kcms/detail/31.1283.s.20200908 .1125.002.html (accessed on 10 September 2020).

27. Li, X.M.; Zhang, S.Y.; Wang, K.; Chen, L.R.; Chen, T.H. Effect of annual temperature variation on growth of Sargassum horneri in Gouqi Island. Oceanol. Limnol. Sin. 2020, 51, 1136-1143.

28. Huang, B.X.; Ding, L.P.; Qiang, H.T.; Sun, G.D. Species diversity and distribution of genus sargassum in China Seas. Oceanol. Limnol. Sin. 2013, 44, 69-76.

29. Ta, C.H. An Outline on the Regionalisation of the Global Flora. Acta Sci. Nat. Univ. Sunyatseni 1994, 33, 73-80.

30. Zhang, S.J. The species and distribution of seaweeds in the coast of China seas. Chin. Biodivers. 1996, 4, 139-144.

31. Liu, Z.Y.; Pang, Y.L.; Guo, W.; Qing, S. Relationship between floating seaweeds and seaweed flora. Studia Mar. Sin. 2016, 51, 323-327.

32. Liu, Z.Y. Biogeographical Distribution of Seaweeds in Typical Areas of Bohai Sea and Yellow Sea. Ph.D. Thesis, Nanjing Agricultural University, Nanjing, China, 2014.

33. Airoldi, L. The effects of sedimentation on rocky coast assemblages. Oceanogr. Mar. Biol. 2003, 41, 161-236.

34. Tseng, C.K. Some problems concerning analytical studies of marine algal flora. Oceanol. Et Limnol. Sin. 1963, 5, $298-305$.

35. Cheng, X.P. Response of Photosynthetic Activity of Large Seaweed to Different Environmental Conditions. Master's Thesis, Shanghai Ocean University, Shanghai, China, 2019.

36. Xiang, S.D.; Ruan, J.H. Checklist and the floral analysis of benthic seaweeds in Zhej iang Province. J. Zhe Jiang Univ. Sci. Ed. 2002, $29,548-557$.

37. Liao, Z.H.; Yu, K.F.; Wang, Y.H. Review on the effect of macroalgae on the degeneration of coral reefs. Acta Ecol. Sin. 2016, 36, 6687-6695.

38. Luo, H.Y. The Distribution Characteristics of Turf Algae and Its Potential Effect on Scleractinia Coral in the Reefs of Mid-Northern South China Sea. Master's Thesis, Guangxi University, Nanning, China, 2019.

39. Wu, B.Y. Kuroshio and circulations in China seas. J. Oceanogr. Taiwan Strait 1991, 33, 36-44.

40. Zeng, J.; Wu, X.Y.; Liao, X.X.; Yang, S.G.; Huang, M.; Tang, X.M. Effects of temperature on the uptake capacities of five large seaweeds for nitrogen and phosphorus. Chin. Fish. Qual. Stand. 2020, 10, 31-37.

41. Tseng, C.K.; Chang, C.F. An analysis of the nature of marine algal flora. Oceanol. Limnol. Sin. 1960, 3, 177-187.

42. Tseng, C.K.; Chang, C.F. An analytical study of the marine algal flora of the Western Yellow Sea coast. Oceanol. Limnol. Sin. 1962, 4, 49-59.

43. Xia, B.M.; Wang, G.C.; Wang, Y.Q. The benthic algal flora recorded in Sansha region, South China Sea and comparison with those of related areas. Oceanol. Limnol. Sin. 2013, 44, 1681-1704. 